\title{
Aplikasi Penginderaan Jauh Dalam Pemetaan Penggunaan Lahan Detil Tapak RDE, PUSPIPTEK Serpong
}

\author{
Heni Susiati ${ }^{* 1}$, Habib Subagio ${ }^{2}$ \\ ${ }^{1}$ Pusat Kajian Sistem Energi Nuklir, BATAN, Jl. Kuningan Barat, Mampang Prapatan, Jakarta Selatan,Indonesia 12710 \\ ${ }^{2}$ Pusat Pemetaan dan Tataruang, Badan Informasi Geospasial, Jl. Raya Bogor, Jawa Barat, Indonesia
}

\begin{tabular}{l}
\hline INFORMASI ARTIKEL \\
\hline Riwayat Artikel: \\
Diterima: \\
13 Februari 2017 \\
Diterima dalam bentuk revisi: \\
17 Februari 2017 \\
Disetujui: \\
1 Maret 2017 \\
\end{tabular}

Kata kunci:

Penginderaan jauh,

Pemetaan,

RDE,

Pemukiman

\begin{abstract}
ABSTRAK
APLIKASI PENGINDERAAN JAUH DALAM PEMETAANPENGGUNAAN LAHAN DETIL TAPAK RDE, PUSPIPTEK SERPONG. Telah dilakukan pemetaan tutupan lahan dan perkembangannya dalam skala detil $(1: 5.000)$ dengan radius $5 \mathrm{~km}$ dari pusat tapak rencana pembangunan Reaktor Daya Eksperimental (RDE) di Kawasan Nuklir Serpong (KNS), PUSPIPTEK Serpong. Tujuan penelitian adalah untuk membuat database penggunaan lahan skala detil 1:5.000 sebagai persiapan dalam rencana pembangunan RDE dan melengkapi peta tutupan lahan skala 1: 10.000. Metode penelitian dilakukan dalam beberapa tahap, yaitu pengumpulandan pengolahan data citra, ground check lapangan, analisis penggunaan lahan radius $300-500 \mathrm{~m}$, radius $1,2,3,4$, dan $5 \mathrm{~km}$ dari tapak $R D E$, serta perubahan penggunaan lahan tahun 2014-2015. Pengolahan citra satelit dilakukan di Pusat Pemetaan dan Tataruang, Badan Informasi Geospasial (BIG). Pengolahan data menggunakan program ArcGis dan Er Mapper, sedangkan analisis data citra satelit menggunakan Image Analysis yang merupakan salah satu tool dalam ArcGis. Hasil penelitian menunjukkan bahwa tutupan lahan KNS setelah radius $3 \mathrm{~km}$ merupakan pemukiman yang padat di berbagai tempat. Perubahan penggunaan lahan pada tahun 2014-2015 menunjukkan bahwa terjadi perkembangan pesat pemukiman ditunjukkan dengan peningkatan luasan pemukiman di bagian Utara - Timur kawasan PUSPIPTEK.
\end{abstract}

\begin{abstract}
THE APPLICATION OF REMOTE SENSING IN DETAIL LAND USE MAPPING OF RDE SITE, PUSPIPTEK SERPONG. Land cover mapping and its development has been performed in a detail scale (1:5000) within the radius of $5 \mathrm{~km}$ from the center of Experimental Power Reactor (RDE) site at Kawasan Nuklir Serpong (KNS), PUSPIPTEK Serpong. The objective of this study is to establish land cover database in a detail scale 1:5000 as part of the preparation toward RDE development plan and also to complete the land cover map of a scale 1:10.000. The research method is accomplished in several stages, namely data collection and processing of high-resolution satellite imagery and aerial photographs, field surveys, land use analysis within the radius of $300-500 \mathrm{~m}, 1 \mathrm{~km}, 2 \mathrm{~km}, 3 \mathrm{~km}, 4 \mathrm{~km}$ and $5 \mathrm{~km}$ from the RDE site as well as analysis of land use change by 2014-2015. Satellite image processing is carried out at Center for Land Mapping and Atlas, Badan Informasi Geospasial (BIG). Data processing is done by using ArcGis and Er Mapper software, whereas the satellite image analysis is executed by using Image Analysis as one of tool in ArcGis software. The result shows that KNS land cover outside the radius of $3 \mathrm{~km}$ is a dense residential in many places. Analysis of land use change by year 20142015 shows that vast development of residential has occur which demonstrated by the increase of residential area in North-East of PUSPIPTEK.
\end{abstract}

Keywords: remote sensing, mapping, RDE, settlements

() 2016 Jurnal Pengembangan Energi Nuklir. All rights reserved

\section{PENDAHULUAN}

Penggunaan penginderaan jauh (inderaja) mempunyai keunggulan dalam menyajikan informasi keruangan terkait dengan kenampakan fisik dari suatu wilayah, sehingga menguntungkan dalam melakukan penelitian kewilayahan. Penginderaan jauh termasuk foto udara dapat digunakan untuk berbagai macam bidang kajian, salah satunya

*Penulis korespondensi.

E-mail: heni_susiati@batan.go.id adalah pemetaan penggunaan lahan sebagai data dasar (baseline)[1,2].

Dalam kegiatan persiapan pembangunan Reaktor Daya Eksperimental (RDE), perlu dilakukan evaluasi tapak, diantaranya adalah Aspek Tataguna Lahan[3,4]. Evaluasi Tapak ini dilakukan guna memenuhi Peraturan Kepala BAPETEN Nomor 5 Tahun 2007 tentang Peraturan Keselamatan Evaluasi Tapak Reaktor Nuklir dan panduan IAEA [5,6].

Program evaluasi tapak terdiri atas ketentuan dan kegiatan yang dilaksanakan 
untuk evaluasi dan karakterisasi tapak RDE guna memastikan terpenuhinya semua persyaratan BAPETEN. Kawasan PUSPIPTEK Serpong telah menjadi tapak Reaktor Serbaguna (RSG) G.A Siwabessy sejak tahun 1983. Karena lokasi Tapak RDE berada dikawasan yang sama dengan Reaktor G.A Siwabessy maka data sekunder yang relevan dapat dimanfaatkan untuk evaluasi tapak RDE.

Perencanaan pembangunan dan
pengembangan $\mathrm{RDE}$ memerlukan dukungan data dan informasi kewilayahan (keruangan/spasial) yang komprehensif dan mutakhir. Salah satu informasi yang sangat penting adalah data tutupan/penggunaan lahan kawasan sekitar RDE. Data ini akan memberikan informasi mengenai jenis dan sebaran tutupan/penggunaan lahan yang selanjutnya dapat digunakan untuk berbagai macam analisis seperti potensi dan dampak bahaya dari RDE. Selain itu jika data tutupan lahan ini diintegrasikan dengan data spasial lain seperti data administrasi wilayah akan bermanfaat pada analisis distribusi informasi yang terintegrasi dari tiap wilayah tersebut[7,8]. Identifikasi penggunaan lahan juga diperlukan sebagai masukan pada perhitungan dosis radiasi[9].

Teknologi inderaja, dalam hal ini citra satelit beresolusi tinggi, dipandang sebagai metode yang tepat untuk memperoleh data tutupan/penggunaan lahan. Teknologi inimampu meliput wilayah yang luas, mutakhir, tersedia dengan berbagai tingkat kerincian sesuai keperluan, serta semakin mudah dan murah dalam memperolehnya. Pembuatan peta tutupan lahan secara manual dengan pemetaan langsung di lapangan akan sangat mahal biayanya bila dibandingkan dengan interpretasi foto udara[10].

Tujuan penelitian adalah untuk membuat database penggunaan lahan detil (skala 1:5.000) hasil interpretasi dari citra satelit resolusi tinggi dan foto udara kawasan RDE. Penelitian ini merupakan kelanjutan dari penelitian pemetaan tataguna lahan skala 1: 10.000 yang dipandang belum detil[11].

Hasil penelitian ini diharapkan dapat menjadi acuan dalam melakukan identifikasi potensi dan dampak bahaya wilayah dekat (near regional), sekitar tapak (site vicinity) dan area tapak (site area)RDE serta identifikasi upaya mitigasi yang dibutuhkan.

\section{METODOLOGI}

\subsection{Lokasi Penelitian}

Lokasi penelitian mencakup radius $5 \mathrm{~km}$ dari pusat tapak rencana pembangunan RDE, yang berjarak $\pm 600 \mathrm{~m}$ dari RSG Siwabessy diPUSPIPTEK Serpong[12].

\subsection{Bahan dan Alat}

Bahan yang digunakan dalam penelitian ini antara lain: Peta Rupa Bumi Indonesia (RBI) tahun 1999 berskala 1: 25.000,citra resolusi tinggi WorldView 2014, dan foto udara 2015. Alat yang digunakan adalah GPS dan perangkat lunak ER Mapper\& Arc Gis[12].

\subsection{Pengolahan Citra Foto Udara}

Pengolahan citra satelit dilakukan di Pusat Pemetaan dan Tata Ruang, Badan Informasi Geospasial (BIG). Pengolahan citra foto udara meliputi[11]:

a. Pengumpulan data primer berupa foto udara dan hasil pengambilan data menggunakan GPS.

b. Koreksi foto udara dengan koreksi geometrik dan radiometrik.

c. Mosaik foto udara untuk menggabungkan foto udara yang saling berhubungan agar menjadi foto udara yang utuh dan menampilkan daerah yang lebih luas sehingga interpretasi citra dalam radius 5 $\mathrm{km}$ dapat terpenuhi.

d. Interpretasi foto udara dilakukan untuk memperoleh informasi penggunaan lahan tahun 2015. Kelas penggunaan lahan dilakukan dengan melakukan klasifikasi penggunaan lahan sesuai Rancangan Standar Nasional Indonesia (RSNI) tutupan lahan skala 1:10.000 dan Peta Rencana Detail Tata Ruang (RDTR)[12].

\section{HASIL DAN PEMBAHASAN}

Dari hasil interpretasi citra satelit diperoleh 21 kelas tutupan/penggunaan lahan yang ditemui diwilayah penelitian, meliputi: 1 . Bandara; 2. Gedung; 3. Gosong sungai; 4. Jalan; 5. Kebun; 6. Kolam; 7. Lapangan olah raga; 8. Lapangan diperkeras; 9. Pemakaman; 
10. Parkir; 11. Rumput; 12. Rel kereta api; 13. Rawa; 14. Semak belukar; 15. Situ; 16. Sungai; 17. Sawah; 18. Tanah kosong; 19. Tegalan lading; 20. Tempat pembuangan akhir; 21. Taman. Hasil interpretasi foto udara menggunakan metode on screen, dimana resolusi spasialnya sangat tinggi sehingga memberikan informasi yang detil untuk output peta skala 1:5.000. Tahun perekaman citra dilakukan padabulan Mei 2015 dan uji lapangannyadilakukan pada Agustus 2015, sehingga tidak terlalu banyak perbedaan antara data hasil interpretasi dan hasil cek lapangan.

Aplikasi inderaja dapat diterapkan bersama dengan Sistem Informasi Geografis (SIG) untuk penelitian pemetaan tataguna lahan, yakni dalam hal pengukuran (measurement), pemetaan (mapping), dan pemantauan (monitoring). Berdasarkan integrasi inderaja dan SIG, setiap jenis penggunaan lahan dapat diketahui persebarannya secara spasial dan dihitung luasannya sehingga dapat dilakukan analisis spasial serta dapat dipetakan. Integrasi inderaja dan SIG ini akan menghasilkan informasi yang cukup baik, serta efisien baik dari segi waktu maupun biaya sehingga akan mempermudah dalam melakukan perencanaan dan pengambilan keputusan[1,12-14].

Berdasarkan hasil analisis foto udara, diperoleh hasil perhitungan luasan untuk setiap tutupan lahan yang berada pada radius s/d 5 km dari tapak RDE.

\subsection{Penggunaan Lahan Kawasan Puspiptek}

Klasifikasi penggunaan lahan terkait aktivitas pemanfaatan lahan oleh manusia, menggunakan klasifikasi 21 kelas yang merupakan hasil interpretasi foto udara dan World View. Kelas gedung merepresentasikan permukiman, fasilitas, industri, dan gudang berdasarkan interpretasi yang dilakukan pada atap bangunan.

Identifikasi penggunaan lahan Kawasan PUSPIPTEK mendukung analisis dispersi untuk mengetahui dampak RDE terhadap penggunaan lahan kawasan tersebut. Analisis penggunaan lahan ini dilakukan pada radius 300 meter, 500 meter, 1.000 meter, 2.000 meter, 3.000 meter, 4.000 meter dan 5.000 meter. Pembagian radius tersebut dilakukan untuk mengetahui karakteristik pemanfaatan lahan sehingga dapat dibuat strategi mitigasi apabila terjadi dampak dari $\mathrm{RDE}[3-5]$.

\subsubsection{Penggunaan Lahan Radius 300 Meter}

Wilayah radius 300 meter berada di Kecamatan Setu, Kota Tangerang Selatan. Secara umum penggunaan lahan di sekitar RDE didominasi oleh karakteristik rural dimana penggunaan lahan berupa lahan non terbangun (Gambar 1). Penggunaan lahan kebun cukup dominan seluas 17,55 Ha atau $62,11 \%$ dari luas radius 300 meter.Sebagian kawasan status kepemilikannya adalah lahan milik negara yang dimanfaatkan untuk kawasan perkantoran Kementerian Ristekdikti antara lain BATAN, LIPI, dan BPPT.Penggunaan lahan kebun masih cukup dominan seluas 17,55 Ha atau $62,11 \%$ dari luas radius 300 meter.

Bangunan dalam radius 300 meter memiliki luasan 2,01 Ha atau 7,11\% dari luas penggunaan lahan dalam radius ini. Bangunan tersebut sebagian merupakan kawasan perkantoran, dimana bangunan tersebut memiliki luasan cukup besar karena merupakan sarana laboratorium dan perkantoran untuk mendukung penelitian di kawasan Puspiptek.

Pada radius 300 meter terdapat lahan pertanian berupa tegalan seluas 0,99 $\mathrm{Ha}$ $(3,50 \%)$ dan sawah seluas 0,43 Ha $(1,51 \%)$ (Gambar 1). Keberadaan lahan pertanian di kawasan tersebut menggambarkan aktivitas sebagian masyarakat sekitar yang bekerja pada sektor pertanian. Selain itu terdapat kolam seluas 0,52 Ha (1,84\%).

Kegiatan RDE pada radius 300 meter diperkirakan tidak memberikan dampak yang besar bagi kegiatan masyarakat sekitar baik pada waktu konstruksi maupun operasi, karena pada radius tersebut tidak terdapat kawasan permukiman dalam jumlah besar. Bangunan yang ada sebagian besar merupakan fasilitas pendukung RSG (Reaktor Serba Guna) Siwabessy yang sudah dibangun sejak 1983. Sebagian besar lahan di radius 300 meter merupakan lahan lembaga yang berada di dalam koordinasi Kementerian Ristekdikti sehingga arahan untuk mitigasi dapat dilakukan secara terpadu untuk internal instansi tersebut. 


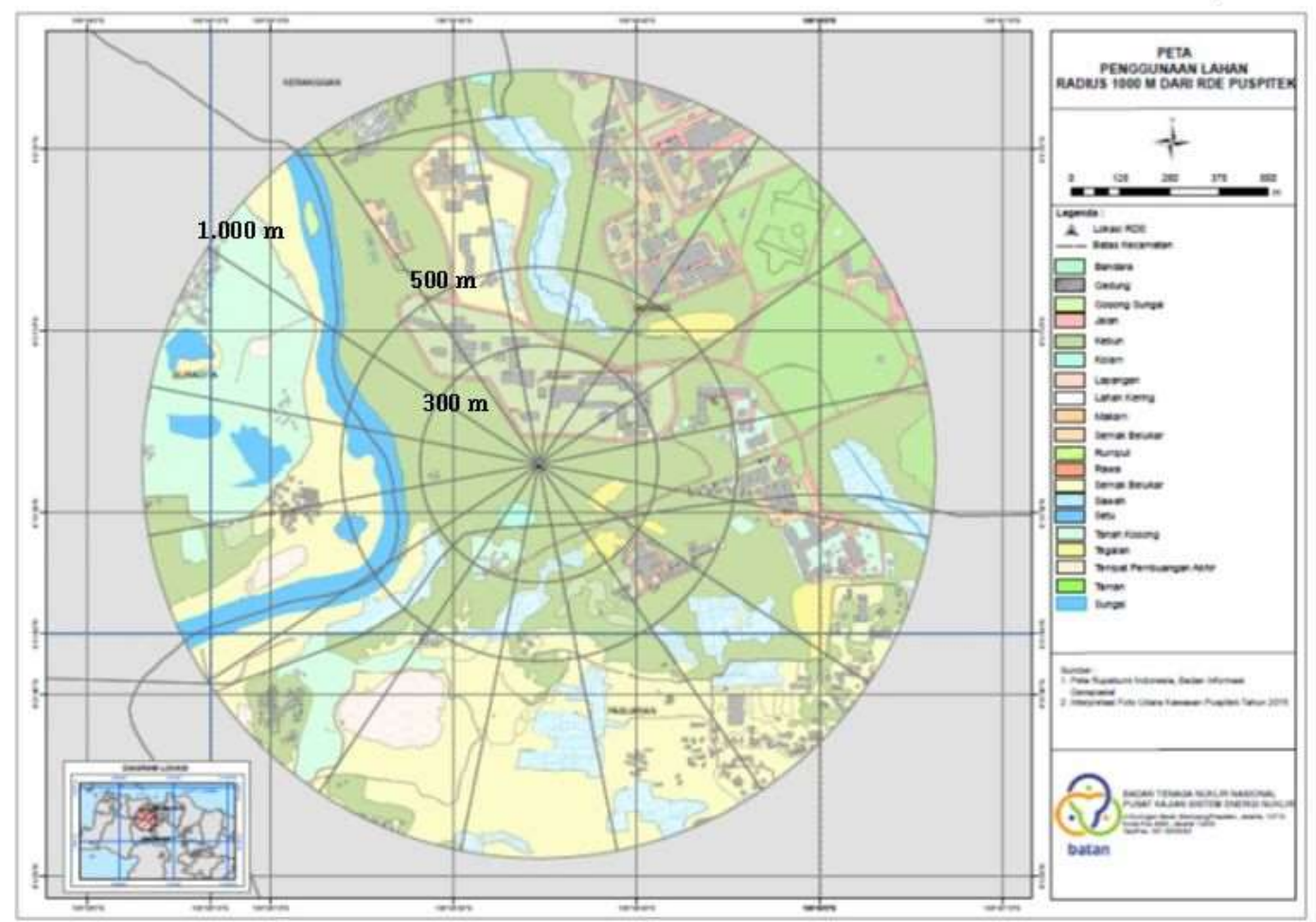

Gambar 1. Peta Penggunaan Lahan Radius 300, 500, dan 1.000 m RDE Puspiptek.

Pada radius 300 meter, hanya terdapat 9 klasifikasi penggunaan lahan, yaitu gedung, jalan, kebun, kolam, rumput, semak belukar, sawah, tanah kosong dan tegalan. Penggunaan lahan kebun lebih mendominasi dibandingkan penggunaan lahan lainnya.

\subsubsection{Penggunaan Lahan Radius 500 Meter.}

Penggunaan lahan pada radius 500 meter berada di Kecamatan Setu, Kota Tangerang Selatan, Kecamatan Gunungsindur, Kabupaten Bogor dan sebagian kecil Kecamatan Cisauk, Kabupaten Tangerang. Secara umum penggunaan lahan radius 500 meter memiliki karakteristik yang sama dengan penggunaan lahan radius 300 meter (Gambar 1).

Penggunaan lahan kebun masih memiliki luasan yang dominan yaitu seluas 42,08 Ha $(53,58 \%)$, sebagian merupakan kebun campuran yang terdistribusi merata di kawasan radius 500 meter. Rumput juga memiliki cakupan yang cukup besar seluas 10,77 Нa (13,72\%).

Semak belukar memiliki luasan 6,26 $\mathrm{Ha}$ $(7,98 \%)$ yang terdistribusi di bagian barat dan selatan kawasan pada radius 500 meter. Semak belukar berada di luar perkantoran
PUSPIPTEK, sebagian besar berada di sempadan sungai Cisadane. Di sempadan sungai Cisadane terdapat banyak pemukiman illegal. Sempadan tersebut tidak dimanfaatkan untuk lahan terbangun agar fungsi dan keberadaan sungai tidak terganggu. Keputusan Presiden No. 32/1990 menyatakan bahwa sempadan sungai adalah kawasan perlindungan wilayah setempat.Meskipun demikian, berbagai pelanggaran terhadap peraturan perundangan terus terjadi, termasuk banyaknya pemukiman ilegal di kawasan sempadan sungai Cisadane yang memunculkan bahaya lingkungan $[15,16]$

Pada radius ini belum banyak terdapat pemukiman sehingga aktivtitas RDE belum banyak memberikan dampak langsung terhadap masyarakat. Dampak yang mungkin ditimbulkan dari kegiatan RDE adalah pada lahan pertanian. Lahan pertanian pada radius ini antara lain sawah seluas 4,40 Ha (5,60\%) dan tegalan seluas 1,56 Ha (1,99\%). Sawah terdistribusi pada bagian utara dan selatan di luar kawasan perkantoran Puspitek, sedangkan tegalan berada di bagian timur dan tengah kawasan PUSPIPTEK khususnya di Kecamatan Setu.

Pada radius 500 meter, terdapat 13 klasifikasi penggunaan lahan, yang meliputi klasifikasi seperti pada radius $300 \mathrm{~m}$ ditambah dengan lahan parkir, situ, sungai dan taman. 


\subsubsection{Penggunaan Lahan Radius 1.000 Meter}

Penggunaan lahan pada radius 1.000 meter berada di Kecamatan Setu, Kota Tangerang Selatan, Kecamatan Gunungsindur, Kabupaten Bogor dan sebagian kecil Kecamatan Cisauk, Kabupaten Tangerang.Karakteristik penggunaan lahan pada radius 1.000 meter sedikit berbeda. Kebun memiliki cakupan paling luas yaitu sebesar 93,61 Ha (29,80\%), namun persentasenya sudah banyak berkurang. Kebun banyak berada di sekitar pusat RDE. Semak belukar memiliki luas 66,91 Ha (21,30\%). Semak belukar terdistribusi di Kecamatan Cisauk dan Kecamatan Gunungsindur. Semak belukar di Kecamatan Cisauk merupakan lahan yang berada di kawasan pengembangan perumahan. Kawasan yang siap bangun direpresentasikan dalam penggunaan lahan tanah kosong, sedangkan lahan yang belum siap bangun dan membutuhkan waktu untuk pengembangannya biasanya berupa semak belukar (Gambar 2).

Semak belukar di Kecamatan Gunungsindur berada di sekitar lahan pertanian dan rawa. Semak belukar tersebut belum dimanfaatkan secara optimal. Lahan tersebut dapat dimanfaatkan sebagai lahan pertanian seperti tegalan.

Pada radius ini, sudah banyak dijumpai pemukiman berupa perkampungan dan sebagian komplek perumahan. Pemukiman dimasukkan dalam klasifikasi gedung karena interpretasi yang dilakukan pada atap bangunan. Gedung memiliki luasan 20,41 Ha (6,50\%). Pemukiman memiliki pola yang mengelompok (cluster) pada perkampungan dan sebagian linear mengikuti jalan.

Penggunaan lahan situ terdapat di Kecamatan Cisauk memiliki luas 3,09 Ha $(0,98 \%)$. Sedangkan rawa terdapat di
Kecamatan Gunungsindur dengan luasan 5,11 Ha $(1,63 \%)$. Secara umum tubuh air yang terdapat dalam radius ini antara lain situ, sungai, dan kolam. Pada radius ini terdapat Sungai Cisadane yang memisahkan Kota Tangerang Selatan dan Kabupaten Tangerang.

Penggunaan lahan situ terdapat di Kecamatan Cisauk yang memiliki luas 3,09 Ha $(0,98 \%)$. Sedangkan rawa terdapat di Kecamatan Gunungsindur dengan luasan 5,11 Ha (1,63\%). Secara umum tubuh air yang terdapat dalam radius ini antara lain situ, sungai, dan kolam. Pada radius ini terdapat Sungai Cisadane yang memisahkan Kota Tangerang Selatan dan Kabupaten Tangerang.

Penggunaan lahan situ terdapat di Kecamatan Cisauk yang memiliki luas 3,09 Ha $(0,98 \%)$. Sedangkan rawa terdapat di Kecamatan Gunungsindur dengan luasan 5,11 Ha $(1,63 \%)$. Secara umum tubuh air yang terdapat dalam radius ini antara lain situ, sungai, dan kolam.Strategi mitigasi perlu direncanakan agar program kedaruratan nuklir untuk kawasan RDE dapat disusun.

\subsubsection{Penggunaan Lahan Radius 2.000 Meter}

Penggunaan lahan pada radius 2.000 meter berada di Kecamatan Setu, Kota Tangerang Selatan, Kecamatan Gunungsindur dan Kecamatan Rumpin, Kabupaten Bogor dan Kecamatan Cisauk, Kabupaten Tangerang. Karakteristikpenggunaan lahan radius 2.000 meter hampir sama dengan penggunaan lahanradius 1.000 meter.

Secara umum semak belukar merupakan penggunaan yang luasannya paling besar yaitu sebesar 296,75 Ha (26,63\%). Semak belukar terdistribusi di semua kecamatan pada radius tersebut. Sebagian besar semak belukar berada di sekitar pusat kegiatan RDE di komplek Puspiptek. 


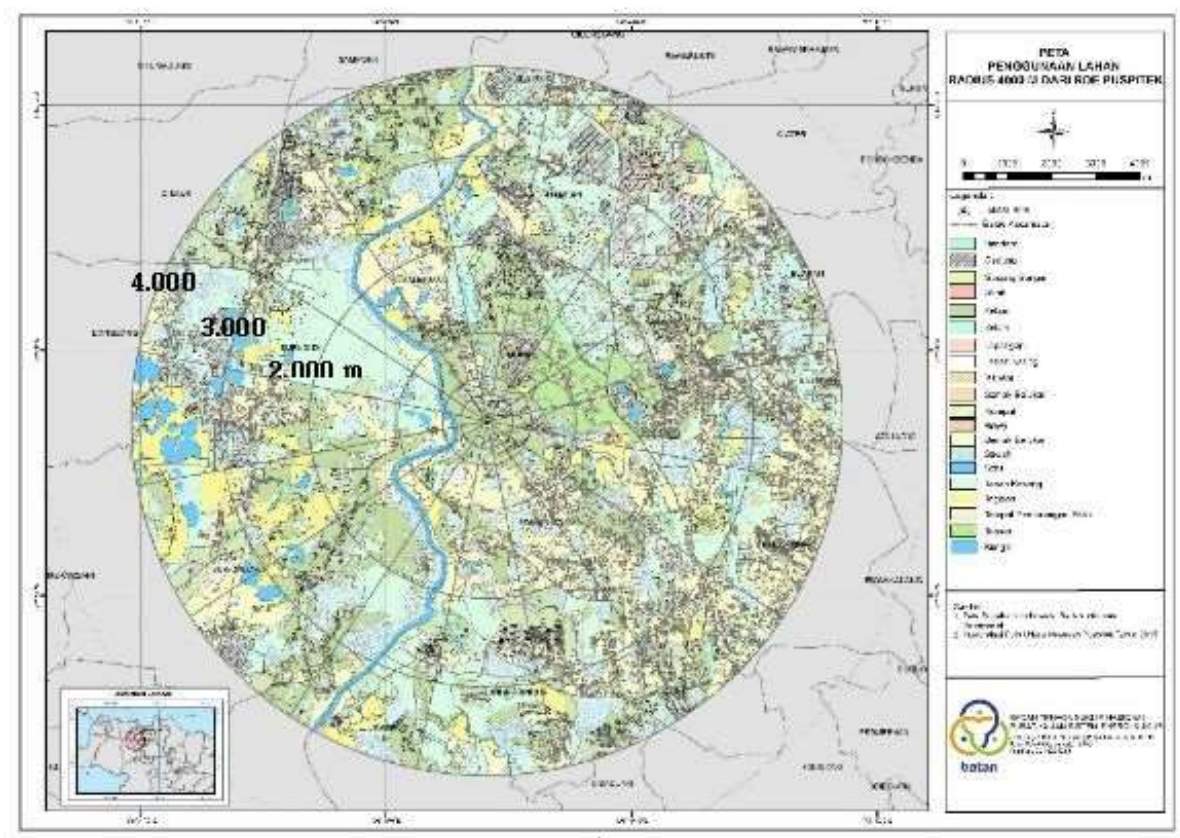

Gambar 2. Peta Penggunaan Radius 2.000, 3.000 dan 4.000 Meter RDE Puspiptek

Luasan tanah kosong sebesar 170,96 Ha $(13,61 \%)$ dan sebagian besar berada di Kecamatan Cisauk. Pengembangan kawasan perumahan BSD (Bumi Serpong Damai) mengarah ke Kecamatan Cisauk. Kondisi Kecamatan Serpong yang sudah mengalami titikjenuh menyebabkan perlunya pengembangan kawasan baru untuk perluasan kawasan perumahan. Ketersediaan lahan yang masih cukup luas dengan penggunaan lahan eksisting berupa areal non terbangun menyebabkan Kecamatan Cisauk sangat potensial untuk dikembangkan. Hambatan fisik berupa Sungai Cisadane tidak banyak berpengaruh terhadap pengembang besar. Kondisi saat ini jalan sebagai infrastruktur penunjang pengembangan perumahan sudah tersedia. Tanah kosong pada wilayah tersebut sudah siap bangun, besar kemungkinan dalam kurun waktu 2-3 tahun sudah berubah menjadi kawasan pemukiman.

Pada radius 2.000 meter ini juga dijumpai beberapa fasilitas umum berupa lapangan olah raga seluas $0,46 \mathrm{Ha}(0,004 \%)$ dan lapangan diperkeras seluas 0,24 $\mathrm{Ha}$ $(0,02 \%)$. Lapangan olah raga berupa lapangan sepakbola yang memiliki ciri bentuk lapangan persegi panjang dan terdapat kenampakan gawang pada lebar lapangan tersebut. Lapangan diperkeras merupakan fasilitas olah raga berupa lapangan tenis, bulutangkis, dan basket

\subsubsection{Penggunaan Lahan Radius 3.000 Meter}

Penggunaan lahan pada radius 3.000 meter berada di Kecamatan Setu, Kota Tangerang Selatan, Kecamatan Gunungsindur dan Kecamatan Rumpin, Kabupaten Bogor dan Kecamatan Cisauk, serta Kabupaten Tangerang. Penggunaan lahan semak belukar dan tanah kosong menempati luasan dominan masing-masing seluas 612,27 Ha (21,66\%) dan 516,57 На (18,28\%). Penggunaan lahan tanah kosong arah pengembangannya sebagai kawasan pemukiman dan lahan terbangun lainnya. Kondisi eksisting gedung yang merepresentasikan pemukiman dan lahan terbangun lainnya menempati luasan 282,65 Ha (10,00\%). Kondisi lahan terbangun di sekitar Kawasan PUSPIPTEK diprediksi akan berubah seiring perkembangan kawasan perumahan yang ada di sekitarnya.

Pada radius ini, lahan pertanian masih tersedia sebesar $16,05 \%$, yang berupa sawah seluas 300,65 Ha (10,64\%) dan tegalan 152,80 Ha $(5,41 \%)$. Tegalan sebagian besar berada di Kecamatan Rumpin dan Kecamatan Gunungsindur. Sedangkan sawah tersebar di semua kecamatan dengan luasan yang tidak terlalu besar. Sawah yang ada merupakan lahan yang sudah bercampur dengan pemukiman karena lahan pertanian banyak mengalami alih fungsi menjadi lahan terbangun (Gambar 3) 


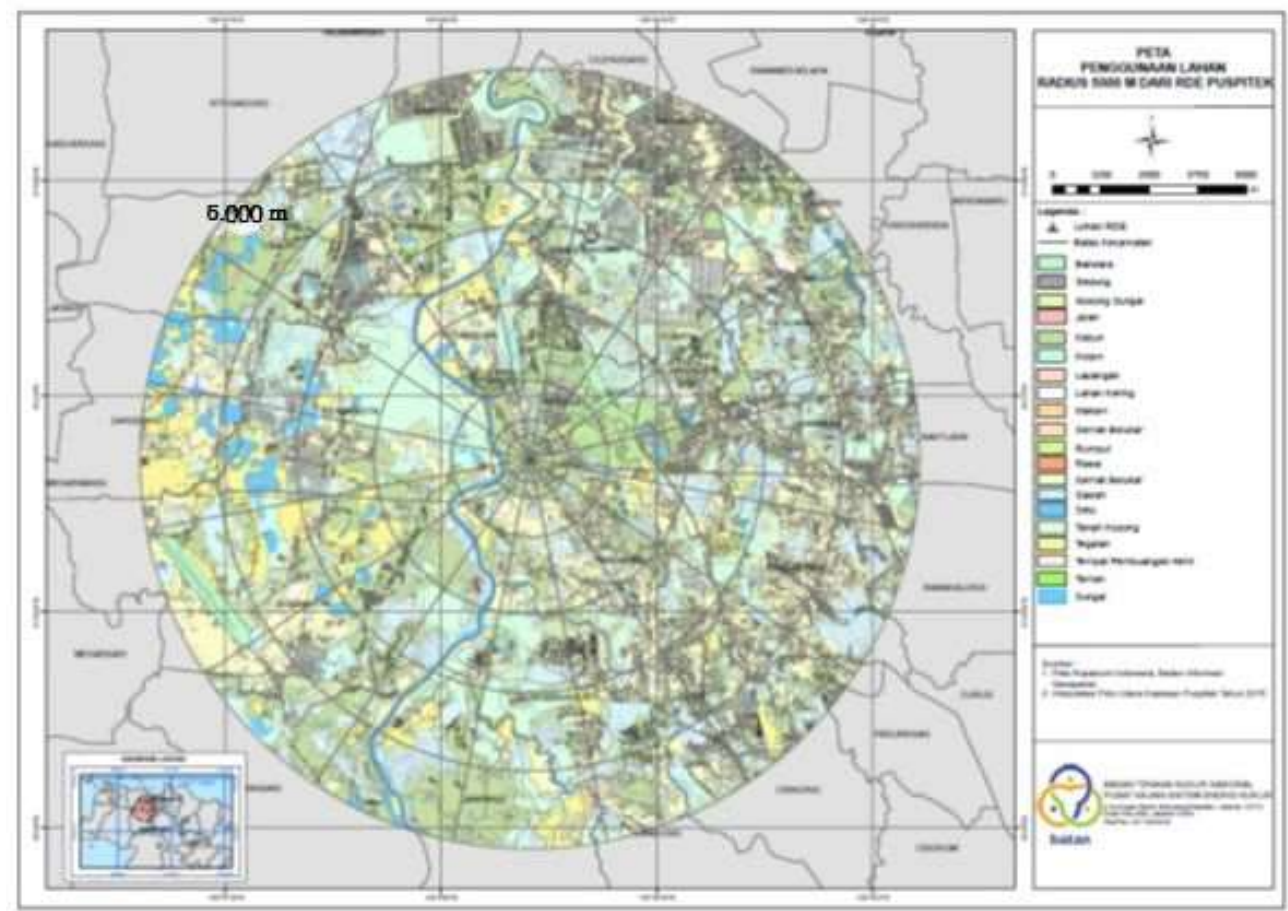

Gambar 3. Peta Penggunaan Radius 5.000 m RDE Puspiptek.

Penggunaan lahan lainnya menempati luasan yang relatif kecil antara lain gosong sungai, lapangan, pemakaman, lahan parkir, rawa, dan situ. Luasan penggunaan lahan tersebut memiliki persentase kurang dari $1 \%$. Penggunaan lahan tersebut sebarannya mengikuti penggunaan lahan lainnya, misal gosong sungai berada di sekitar sungai, lahan parkir berada di kawasan perkantoran dan perdagangan dan jasa.

\subsubsection{Penggunaan Lahan Radius 4.000 Meter}

Penggunaan lahan pada radius 4.000 meter berada di empat wilayah administrasi yang sama dengan penggunaan lahan radius 3.000 meter yakni Kecamatan Setu, Kota Tangerang Selatan, Kecamatan Gunungsindur dan Rumpin, Kabupaten Bogor dan Kecamatan Cisauk, serta Kabupaten Tangerang.

Penggunaan lahan pada radius 4.000 meter memiliki karakteristik yang hampir sama dengan penggunaan lahan radius 3.000 meter. Semak belukar dan tanah kosong masih merupakan penggunaan lahan yang dominan yaitu masing-masing seluas 1.125,28 Ha $(22,39 \%)$ dan 844,61 Ha $(16,81 \%)$. Sebagian lahan tersebut memang dipersiapkan sebagai kawasan pemukiman. Selain itu penggunaan lahan kebun juga memiliki cakupan cukup besar yaitu seluas 636,96 Ha (12,68\%). Kebun banyak bertambah di Kecamatan Cisauk bagian utara.

Lahan pertanian pada radius 4.000 meter sebagian besar berupa sawah yang berada di bagian barat Kecamatan Cisauk. Sawah memiliki luasan 544,39 Ha (10,83\%). Selain di wilayah tersebut, sawah terdistribusi di setiap wilayah kecamatan walaupun dengan luasan yang relatif kecil dan berpencar.

Penggunaan lahan gedung yang sebagian besar berupa pemukiman memiliki luasan 550,46 Ha (10,95\%). Gedung walaupun persentasenya hampir sama dengan penggunaan lahan pada radius 3.000 meter namun luasannya hampir bertambah dua kali lipat yaitu dari 282,65 Ha menjadi 550,46 Ha. Pertambahan tersebut disebabkan mulai banyaknya perumahan yang berada di Kecamatan Serpong dan sebagian kecil Kecamatan Setu (Gambar 3).

Pada radius 4.000 meter ini juga dijumpai fasilitas transportasi berupa rel kereta api. Rel kereta api ini merupakan jalurkereta listrik yang menghubungkan Jakarta-Serpong. Selain itu juga terdapat kereta api jarak menengah yang menghubungkan Jakarta-Rangkasbitung. 
Tabel 1. Luas Penggunaan Lahan Menurut Klasifikasi dan Jarak Terhadap Pusat RDE (Hasil Analisis Pemetaan Foto Udara)

\begin{tabular}{|c|c|c|c|c|c|c|c|}
\hline \multirow{2}{*}{$\begin{array}{c}\text { Klasifikasi Penggunaan } \\
\text { Lahan }\end{array}$} & \multicolumn{7}{|c|}{ Luas Penggunaan Lahan ( $\mathrm{Ha})$} \\
\hline & $\begin{array}{l}\text { Radius } \\
300 \mathrm{~m}\end{array}$ & $\begin{array}{l}\text { Radius } \\
500 \mathrm{~m}\end{array}$ & $\begin{array}{l}\text { Radius } \\
1.000 \mathrm{~m}\end{array}$ & $\begin{array}{l}\text { Radius } \\
2.000 \mathrm{~m}\end{array}$ & $\begin{array}{l}\text { Radius } \\
3.000 \mathrm{~m}\end{array}$ & $\begin{array}{l}\text { Radius } \\
4.000 \mathrm{~m}\end{array}$ & $\begin{array}{l}\text { Radius } \\
5.000 \mathrm{~m} \\
\end{array}$ \\
\hline Bandara & & & & & & & $\begin{array}{r}35,81 \\
0,46 \%\end{array}$ \\
\hline Gedung & $\begin{array}{r}2,01 \\
7,11 \% \\
\end{array}$ & $\begin{array}{r}4,88 \\
6,21 \% \\
\end{array}$ & $\begin{array}{l}20,41 \\
6,5 \% \\
\end{array}$ & $\begin{array}{l}100,83 \\
8,03 \% \\
\end{array}$ & $\begin{array}{r}282,65 \\
10 \% \\
\end{array}$ & $\begin{array}{r}550,46 \\
10,95 \% \\
\end{array}$ & $\begin{array}{r}805,83 \\
10,26 \% \\
\end{array}$ \\
\hline Gosong & & & $\begin{array}{r}0,22 \\
0,07 \% \\
\end{array}$ & $\begin{array}{r}0,86 \\
0,07 \% \\
\end{array}$ & $\begin{array}{r}1,73 \\
0,06 \% \\
\end{array}$ & $\begin{array}{r}1,78 \\
0,04 \% \\
\end{array}$ & $\begin{array}{r}5,32 \\
0,07 \% \\
\end{array}$ \\
\hline Jalan & $\begin{array}{r}0,86 \\
3,05 \% \\
\end{array}$ & $\begin{array}{r}2,8 \\
3,56 \% \\
\end{array}$ & $\begin{array}{r}12,42 \\
3,95 \% \\
\end{array}$ & $\begin{array}{r}37,85 \\
3,01 \% \\
\end{array}$ & $\begin{array}{r}91,8 \\
3,25 \% \\
\end{array}$ & $\begin{array}{l}187,74 \\
3,74 \% \\
\end{array}$ & $\begin{array}{l}295,89 \\
3,77 \% \\
\end{array}$ \\
\hline Kebun & $\begin{array}{r}17,55 \\
62,11 \% \\
\end{array}$ & $\begin{array}{r}42,08 \\
53,58 \% \\
\end{array}$ & $\begin{array}{r}93,61 \\
29,8 \% \\
\end{array}$ & $\begin{array}{r}252,69 \\
20,12 \% \\
\end{array}$ & $\begin{array}{r}416,21 \\
14,73 \% \\
\end{array}$ & $\begin{array}{r}636,96 \\
12,68 \% \\
\end{array}$ & $\begin{array}{r}1.049,17 \\
13,36 \% \\
\end{array}$ \\
\hline Kolam & $\begin{array}{r}0,52 \\
1,84 \% \\
\end{array}$ & $\begin{array}{r}0,52 \\
0,66 \% \\
\end{array}$ & $\begin{array}{r}0,76 \\
0,24 \% \\
\end{array}$ & $\begin{array}{r}19,87 \\
1,58 \% \\
\end{array}$ & $\begin{array}{r}38,67 \\
1,37 \% \\
\end{array}$ & $\begin{array}{l}75,43 \\
1,5 \% \\
\end{array}$ & $\begin{array}{r}107,7 \\
1,37 \% \\
\end{array}$ \\
\hline Lapangan Olah Raga & & & & $\begin{array}{r}0,46 \\
0,04 \%\end{array}$ & $\begin{array}{r}1,02 \\
0,04 \%\end{array}$ & $\begin{array}{r}2,22 \\
0,04 \%\end{array}$ & $\begin{array}{r}8,98 \\
0,11 \%\end{array}$ \\
\hline Lapangan Diperkeras & & & & $\begin{array}{r}0,24 \\
0,02 \% \\
\end{array}$ & $\begin{array}{r}0,3 \\
0,01 \% \\
\end{array}$ & $\begin{array}{r}0,98 \\
0,02 \% \\
\end{array}$ & $\begin{array}{r}1,72 \\
0,02 \% \\
\end{array}$ \\
\hline Pemakaman & & & & $\begin{array}{r}0,41 \\
0,03 \% \\
\end{array}$ & $\begin{array}{r}0,77 \\
0,03 \% \\
\end{array}$ & $\begin{array}{r}5,79 \\
0,12 \% \\
\end{array}$ & $\begin{array}{r}25,74 \\
0,33 \% \\
\end{array}$ \\
\hline Parkir & & $\begin{array}{r}0,17 \\
0,22 \% \\
\end{array}$ & $\begin{array}{r}2,53 \\
0,81 \% \\
\end{array}$ & $\begin{array}{r}5,94 \\
0,47 \% \\
\end{array}$ & $\begin{array}{r}8,17 \\
0,29 \% \\
\end{array}$ & $\begin{array}{r}15,54 \\
0,31 \% \\
\end{array}$ & $\begin{array}{r}19,81 \\
0,25 \% \\
\end{array}$ \\
\hline Rumput & $\begin{array}{r}5,05 \\
17,85 \% \\
\end{array}$ & $\begin{array}{r}10,77 \\
13,72 \% \\
\end{array}$ & $\begin{array}{r}20,65 \\
6,58 \% \\
\end{array}$ & $\begin{array}{r}69,17 \\
5,51 \% \\
\end{array}$ & $\begin{array}{r}196,5 \\
6,95 \% \\
\end{array}$ & $\begin{array}{l}429,31 \\
8,54 \% \\
\end{array}$ & $\begin{array}{l}599,64 \\
7,64 \% \\
\end{array}$ \\
\hline Rel Keretapi & & & & & & $\begin{array}{r}1,13 \\
0,02 \% \\
\end{array}$ & $\begin{array}{r}6,51 \\
0,08 \% \\
\end{array}$ \\
\hline Rawa & & & $\begin{array}{r}5,11 \\
1,63 \%\end{array}$ & $\begin{array}{r}14,29 \\
1,14 \%\end{array}$ & $\begin{array}{r}28,1 \\
0,99 \%\end{array}$ & $\begin{array}{r}42,45 \\
0,84 \%\end{array}$ & $\begin{array}{r}68,93 \\
0,88\end{array}$ \\
\hline Semak Belukar & $\begin{array}{r}0,1 \\
0,37 \% \\
\end{array}$ & $\begin{array}{r}6,26 \\
7,98 \% \\
\end{array}$ & $\begin{array}{r}66,91 \\
21,3 \% \\
\end{array}$ & $\begin{array}{r}296,75 \\
23,63 \% \\
\end{array}$ & $\begin{array}{r}612,27 \\
21 \% \\
\end{array}$ & $\begin{array}{r}1.125,28 \\
22,39 \% \\
\end{array}$ & $\begin{array}{r}1.881,10 \\
23,96 \% \\
\end{array}$ \\
\hline Situ & & $\begin{array}{r}0,2 \\
0,25 \% \\
\end{array}$ & $\begin{array}{r}3,09 \\
0,98 \% \\
\end{array}$ & $\begin{array}{r}12,3 \\
0,98 \% \\
\end{array}$ & $\begin{array}{r}28,01 \\
0,99 \%\end{array}$ & $\begin{array}{r}81,62 \\
1,62 \% \\
\end{array}$ & $\begin{array}{l}148,31 \\
1,89 \% \\
\end{array}$ \\
\hline Sungai & & $\begin{array}{r}3,54 \\
4,5 \% \\
\end{array}$ & $\begin{array}{r}11,59 \\
3,69 \% \\
\end{array}$ & $\begin{array}{r}29,97 \\
2,39 \%\end{array}$ & $\begin{array}{l}53,78 \\
1,9 \%\end{array}$ & $\begin{array}{r}72,77 \\
1,45 \%\end{array}$ & $\begin{array}{l}102,86 \\
1,31 \% \\
\end{array}$ \\
\hline Sawah & $\begin{array}{r}0,43 \\
1,51 \% \\
\end{array}$ & $\begin{array}{r}4,4 \\
5,6 \% \\
\end{array}$ & $\begin{array}{r}21,6 \\
6,88 \% \\
\end{array}$ & $\begin{array}{l}115,44 \\
9,19 \% \\
\end{array}$ & $\begin{array}{r}300,65 \\
10,64 \% \\
\end{array}$ & $\begin{array}{r}544,39 \\
10,83 \% \\
\end{array}$ & $\begin{array}{r}957,76 \\
12,20 \% \\
\end{array}$ \\
\hline Tanah Kosong & $\begin{array}{r}0,75 \\
2,67 \% \\
\end{array}$ & $\begin{array}{r}1,06 \\
1,35 \% \\
\end{array}$ & $\begin{array}{r}28,62 \\
9,11 \%\end{array}$ & $\begin{array}{r}170,96 \\
13,61 \\
\end{array}$ & $\begin{array}{r}516,57 \\
18,28 \% \\
\end{array}$ & $\begin{array}{r}844,61 \\
16,81 \%\end{array}$ & $\begin{array}{r}1.142,17 \\
14,55 \%\end{array}$ \\
\hline Tegalan & $\begin{array}{r}0,99 \\
3,5 \% \\
\end{array}$ & $\begin{array}{r}1,56 \\
1,99 \%\end{array}$ & $\begin{array}{r}3,99 \\
1,27 \% \\
\end{array}$ & $\begin{array}{r}33,71 \\
2,68 \\
\end{array}$ & $\begin{array}{r}152,8 \\
5,41 \%\end{array}$ & $\begin{array}{l}296,16 \\
5,89 \%\end{array}$ & $\begin{array}{l}455,8 \\
5,8 \%\end{array}$ \\
\hline Taman & & $\begin{array}{r}0,29 \\
0,37 \% \\
\end{array}$ & $\begin{array}{r}22,59 \\
7,19 \% \\
\end{array}$ & $\begin{array}{r}94,12 \\
7,49 \\
\end{array}$ & $\begin{array}{r}96,28 \\
3,41 \% \\
\end{array}$ & $\begin{array}{r}105,39 \\
2,1 \% \\
\end{array}$ & $\begin{array}{r}128,1 \\
1,63 \% \\
\end{array}$ \\
\hline TPA & & & & & & $\begin{array}{r}5,06 \\
0,10 \%\end{array}$ & $\begin{array}{r}5,06 \\
0,06 \%\end{array}$ \\
\hline Jumlah & $\begin{array}{r}28,26 \\
100 \%\end{array}$ & $\begin{array}{r}78,52 \\
100 \%\end{array}$ & $\begin{array}{r}314,13 \\
100 \%\end{array}$ & $\begin{array}{r}1.255,85 \\
100 \%\end{array}$ & $\begin{array}{r}2.826,28 \\
100 \%\end{array}$ & $\begin{array}{r}5.025,06 \\
100 \%\end{array}$ & $\begin{array}{r}7.852,19 \\
100 \% \\
\end{array}$ \\
\hline
\end{tabular}

\subsubsection{Penggunaan Lahan Radius 5.000 Meter}

Penggunaan lahan radius 5.000 meter menggambarkan penggunaaan lahan di Kecamatan Setu dan Serpong, Kota Tangerang Selatan, Kecamatan Gunungsindur dan Rumpin, Kabupaten Bogor, dan Kecamatan Cisauk dan Pagedangan, Kabupaten Tangerang.

Secara umum penggunaan lahannya meliputi: semak belukar, tanah kosong, dan kebun yang masih memiliki luasan dominan diatas $1.000 \mathrm{Ha}$, masing-masing dengan luasan 1.811,10 Нa (23,96\%), 1.142,17 $\mathrm{Ha}$ $(14,55 \%)$, dan $1.049,17$ Ha (13,36\%). Semak belukar dan tanah kosong banyak berada di sekitar kawasan perumahan karena kedua jenis penggunaan lahan tersebut potensial berubah dan berkembang menjadi kawasan pemukiman. Sedangkan kebun berada di sekitar pemukiman/perkampungan yang keberadannya bercampur dengan perkampungan penduduk. Lahan pertanian berupa sawah dan tegalan luasannya juga cukup besar yakni seluas 957,76 Ha (12,20\%) dan 455,80 Ha (5,80\%). Lahan pertanian masih banyak tersedia mulai radius 3.000 meter.

Penggunaan lahan gedung menempati luasan 805,83 На (10,26\%). Gedung memiliki 
pertambahan yang cukup besar dari 550,46 Ha menjadi 805,83 Ha. Pada bagian utara radius 5.000 meter ini banyak dijumpai permukiman dan fasilitas perdagangan dan jasa. Gedung di kawasan ini antara lain Taman Tekno yang merupakan fasilitas terpadu yang didalamnya terdapat gudang dan industri.

Pada radius ini terdapat fasilitas lapangan terbang yang berada di Kecamatan Rumpin. Lapangan terbang Rumpin merupakan peninggalan Jepang yang berfungsi sebagai lapangan militer, pangkalan udara cadangan (alternate air base) dan landasan udara cadangan (alternate field) bagi pesawat latih dan pesawat militer/sipil yang membutuhkan landasan darurat dalam penerbangannya. Lapangan udara ini mulai digunakan sejak tahun 2012.

Total luas penggunaan lahan pada radius 5.000 meter adalah 7.852,19 Ha. Sebanyak $36 \%$ dari total luas penggunaan lahan berada pada radius 4.000-5.000 meter.

Penggunaan lahan menurut radius diklasifikasikan ke dalam 21 klasifikasi. Secara lebih rinci, klasifikasi penggunaan lahan beserta luasannya pada masing-masing radius dapat dilihat pada Tabel 1. Penggunaan lahan kebun mendominasi radius 0-1.000 meter, sementara pada radius 1.000-5.000 meter, didominasi oleh penggunaan lahan semak belukar.

\subsection{Perubahan Penggunaan Lahan (Neraca Penggunaan Lahan 2014-2015)}

Perubahan penggunaan lahan suatu wilayah mengindikasikan adanya perkembangan suatu wilayah yang dipengaruhi oleh dinamika pertumbuhan penduduk. Perkembangan suatu wilayah dapat mempengaruhi wilayah sekitarnya. Kawasan PUSPIPTEK berada di tiga wilayah administratif yaitu Kecamatan Serpong (Kota Tangerang Selatan), Kecamatan Cisauk \& Pagedangan (Kabupaten Tangerang), dan Kecamatan Rumpin \& Gunungsindur (Kabupaten Bogor). Kawasan ini mengalami perkembangan yang sangat pesat khususnya di bagian utara wilayah penelitian yaitu di Kecamatan Serpong.
Kecamatan Serpong yang memiliki arahan sebagai kawasan permukiman berkembang karena dipengaruhi oleh keberadaan kawasan Megapolitan Jabodetabek dengan Provinsi Jakarta sebagai pusat kegiatannya[11]. Hal tersebut sejalan dengan Perpres Nomor 54/2008 Tentang Penataan Ruang Kawasan Jabodetabekpunjur[12]. Kecamatan Serpong

banyak dikembangkan sebagai kawasan permukiman. Keberadaan lahan yang semakin terbatas di Kecamatan Serpong menyebabkan perluasan kawasan permukiman ke Kecamatan Cisauk yang ketersediaan lahannya masih cukup luas. Pada kurun waktu 3 tahun terakhir, perkembangan permukiman di kawasan ini terjadi secara cepat sehingga penggunaan lahan sangat dinamis terutama perubahan lahan non terbangun menjadi lahan terbangun.

Pada Tabel 2 terlihat ada beberapa pertambahan luasan penggunaan lahan yang terjadi secara cepat. Permukiman dalam kurun waktu setahun bertambah 226,59 Ha. Pertambahan permukiman ditandai dengan semakin banyaknya perumahan baru yang dibangun oleh pengembang. Perkembangan permukiman tersebut diikuti oleh keberadaan fasilitas umum, perdagangan dan jasa. Penggunaan lahan bangunan bertambah seluas 65,25 Ha. Pertambahan tersebut ditandai oleh bertambahnya beberapa pusat perdagangan dan jasa seperti mall, supermarket, dan ruko yang berada di kawasan tersebut

Hasil penelitian sebelumnya yang membahas penggunaan lahan di wilayah Tangerang Selatan, khususnya di kecamatan Serpong dan Setu menyebutkan bahwa pada tahun 2010 pola penggunaan lahan sudah didominasi oleh pemukiman. Kondisi ini menunjukkan bahwa ketersediaan lahan makin berkurang, seiring dengan tingginya kebutuhan pemukiman sebagai akibat dari peningkatan jumlah penduduk[17]. Demikian juga di wilayah kabupaten Bogor, yang sebagian penggunaan lahan di wilayah tersebut dalam radius $5 \mathrm{~km}$ di dominasi dengan lahan terbangun[18]. 
Tabel 2. Perubahan Penggunaan Lahan Tahun 2014-2015

(Hasil Analisis Pemetaan Citra World View dan Foto Udara)

\begin{tabular}{rlrrrr}
\hline No & & 2014 & \multicolumn{3}{c}{ Perubahan } \\
\hline 1 & Bandara & 35,69 & 35,69 & - \\
\hline 2 & Bangunan & 248,27 & 313,52 & $(+)$ & 65.25 \\
\hline 3 & Kebun & $1.802,17$ & $1.079,13$ & $(-)$ & 723.04 \\
\hline 4 & Permukiman & $2.173,76$ & $2.400,35$ & $(+)$ & 226,59 \\
\hline 5 & Rawa & 94,45 & 51,93 & $(-)$ & 42,52 \\
\hline 6 & Rumput/Tanah Kosong & 969,97 & $1.360,40$ & $(+)$ & 390,43 \\
\hline 7 & Sawah Irigasi & $1.037,04$ & 588,18 & $(-)$ & 448,86 \\
\hline 8 & Sawah Tadah Hujan & 7,97 & 4,92 & $(-)$ & 3,05 \\
\hline 9 & Semak Belukar & 420,57 & $1.128,69$ & $(+)$ & 708,12 \\
\hline 10 & Tegalan/Ladang & 799,72 & 626,79 & $(-)$ & 172,93 \\
11 & Tubuh Air & 252,45 & 252,45 & - \\
\hline
\end{tabular}

Dalam perubahan penggunaan lahan ada proses transisi perubahan lahan, yaitu dari lahan pertanian tidak langsung berubah menjadi lahan terbangun tetapi menjadi rumput/tanah kosong ataupun semak belukar. Rumput/tanah kosong mengalami penambahan luasan yang cukup besar seluas 390,43 Ha.

Penggunaan lahan yang berkurang paling besar adalah kebun seluas 723,04 Ha. Kebun banyak berkurang disebabkan keberadaannya yang cukup strategis berada dalam rencana pengembangan kawasan BSD.

Sawah irigasi sebagian besar berada di Kecamatan Gunungsindur dan Kecamatan Cisauk. Sawah jenis ini telah berkurang seluas 448,86 Ha, karena mengalami perubahan lahan untuk kawasan permukiman. Perubahan sawah irigasi sebagian berubah menjadi lahan kosong dan semak belukar sebelum berubah menjadi permukiman. Sawah irigasi di Kecamatan Serpong keberadaannya tidak terlalu luas yang terdistribusi di pinggiran Kecamatan Serpong khususnya di sekitar perkampungan. Lahan pertanian secara umum berkurang luasannya termasuk sawah tadah hujan berkurang seluas 3,05 Ha dan tegalan ladang berkurang seluas 172,93 Ha.

Perubahan penggunaan lahan, seperti lahan sawah menjadi perumahan dan industri, dapat mengancam hilangnya produktivitas tanah dan kelestarian lingkungan. Lahan sawah diyakini dapat mencegah atau mempertahankan lingkungan dari kerusakan karena mampu menahan air, berfungsi sebagai DAM, dan mengurangi erosi[19].
Luas rawa berkurang 45,52 Ha, akibat proses pendangkalan rawa akibat aktivitas manusia. Secara alamiah rawa juga mengalami pendangkalan karena proses sedimentasi. Pada musim hujan, aliran permukaan banyak yang mengalir dan masuk ke lahan rawa sambil membawa material dan tanah. Hal tersebut terjadi karena tangkapan hujan semakin berkurang dan sungai yang banyak berkurang fungsinya akibat kegiatan manusia.

Selain itu, kebanyakan lahan rawa sengaja diurug menggunakan material tanah yang akan digunakan sebagai kawasan permukiman. Sebagian besar rawa dimanfaatkan sebagai permukiman sehingga banyak pengembang yang memperluas kawasan permukiman dengan mengurug rawa tersebut.

Tubuh air berupa situ (danau) dan sungai yang luasannya relatif tetap. Situ tidak akan dikembangkan menjadi kawasan permukiman karena proses pengurugan situ memerlukan material yang cukup banyak. Situ umumnya dipertahankan keberadaannya, terkait fungsi ekologis sebagai tangkapan hujan, selain memiliki fungsi ekonomis dan fungsi estetika. Secara ekonomis situ dapat dimanfaatkan sebagai tempat memelihara ikan khususnya yang berada di permukiman non perumahan. Secara estetika situ memiliki nilai lebih sebagai tempat rekreasi dan memperindah kawasan permukiman, serta sebagai ruang publik untuk rekreasi dan berolah raga, khususnya yang berada di kawasan perumahan. Keberadaan situ biasanya 
terintegrasi dengan taman yang mendukung penyediaan ruang terbuka hijau.

Selain tubuh air, bandara juga tidak berubah luasannya. Dalam kurun 2014 s/d 2015 lapangan terbang Rumpin tidak ada penambahan infrastruktur pendukung bandara baik berupa bangunan maupun landasan pacu yang peruntukannya sebagai landasan cadangan bagi pesawat latih dan pesawat militer/sipil yang membutuhkan landasan darurat dalam penerbangan.

\section{KESIMPULAN DAN SARAN}

\subsection{KESIMPULAN}

Penggunaan lahan pada radius 300-500 $\mathrm{m}$ dan 1-5 $\mathrm{km}$ dari pusat tapak RDE menunjukkan bahwa pemukiman telah mendominasi ruang di wilayah PUSPIPTEK Serpong. Hal ini terlihat dari kondisi pembangunan perumahan di daerah Serpong yang berkembang cukup pesat. Perubahan penggunaan lahan tahun 2014-2015 menunjukkan terjadinya pengalihan fungsi lahan sawah menjadi pemukiman dan industri.

\subsection{SARAN}

Hasil yang diperoleh dalam studi ini, sebaiknya sebagai acuan dalam analisis selanjutnya, terutama terkait program kedaruratan nuklir program RDE di Kawasan PUSPIPTEK.

\section{UCAPAN TERIMA KASIH}

Ucapan terima kasih disampaikan kepada Kepala PKSEN-BATAN yang telah memberikan dukungan dalam kegiatan pemetaan detil Penggunaan Lahan di Serpong. Demikian juga ucapan terima kasih pada rekan kerja di Bidang KDT-PKSEN. Ucapan terima kasih juga disampaikan pada Tim Pusat Pemetaan Tataruang dan ATLAS, BIG (Andika, Moko, Gunawan, Anggun, dkk.) yang telah membantu dalam pengolahan data foto udara.

\section{DAFTAR ACUAN}

[1]. E. Hapsari, S. H. Murti. "Klasifikasi Berbasis Objek pada Citra Pleiades untuk Pemetaan Ketersediaan Ruang Terbuka Hijau di Perkotaan Purwokerto 2013". Prosiding Pertemuan IImiah MAPIN Tahunan XX. 2015.

[2]. Udok, et al. "Mapping Land Use and Land Cover in parts of the Niger Delta for Effective Planning and Administration”. International Journal of Scientific \& Engineering Research. Volume 6, Issue 12, ISSN 2229-5518, December 2015.

[3]. Badan Tenaga Nuklir Nasional. "Program Evaluasi Tapak Reaktor Riset Eksperimen”. Jakarta, 2014.

[4]. Site Evaluation for Nuclear Installations Safety Requirement. IAEA Safety Standards Series No. NS-R3, Vienna, 2003.

[5]. Peraturan Kepala Badan Pengawas Tenaga Nuklir No.5 tahun 2007 tentang Pedoman Ketentuan Keselamatan Evaluasi Tapak Reaktor Nuklir. Jakarta. 2007.

[6]. Safety of New and Existing Research Reactor Facilities in Relation to External Events. IAEA Safety Reports Series No. 41. Vienna. 2005.

[7]. D. N. Martono. "Aplikasi Data Penginderaan Jauh dan Sistem Informasi Geografis untuk Identifikasi Tingkat Keragaman Penggunaan Lahan”. Seminar Nasional Aplikasi Teknologi Informasi 2009 (SNATI) LAPAN. Yogyakarta, 20 Juni 2009, Hal. 27-32.

[8]. A. Sharma, Nikhildev, R. Attri. "Identification of Factors for Site Selection of Thermal Power Plant (TPPS)". International Journal of Advanced Technology in Engineering and Science. Volume No 03, Special Issue No. 01, ISSN (online): 2348 7550, April 2015, 483-490.

[9]. Dispersion of Radioactive Material in Air and Water and Consideration of Population Distribution in Site Evaluation for Nuclear Power Plants. IAEA Safety Guide NS-G-3.2. Vienna, Austria, 2002.

[10]. N. R. Amelia, Akhbar, I. Ariangsih. "Pembuatan Peta Penutupan Lahan Menggunakan Foto Udara yang Dibuat dengan Paramotor di Taman Nasional Lore Lindu (TNLL) (Studi Kasus Desa Pakuli Kecamatan Gumbasa Kabupaten Sigi)". Warta Rimba. Volume 3, Nomor 2, ISSN: 2406-8373, Desember 2015

[11]. H. Susiati, H. Subagio. "Pemetaan Tata Guna Lahan Dalam Rangka Persiapan Pembangunan RDE di Kawasan PUSPIPTEK, Serpong". Prosiding Seminar Nasional Teknologi Energi Nuklir 2015, ISSN: 2355-7524, Bali, Oktober 2015.

[12]. M. R. Abu Zamroh. "Analisis Perubahan Penggunaan Lahan Untuk Permukiman di Kecamatan Kaliwungu dengan Sistem Informasi Geografis". Jurnal Ilmiah Pendidikan Geografi, Volume 2, No. 1, Oktober 2014

[13]. C. W. Baynard. "Remote Sensing Applications: Beyond Land-Use and Land-Cover Change, Advances in Remote Sensing”. http://dx.doi.org/10.4236/ars.2013.23025.

Published Online September 2013, Sientific Research, (http://www.scrip.org/journal/ars), 2013.

[14]. H. Susiati, H. Subagio. "Laporan Penelitian Analisis Spasial Tataruang Kegiatan RDE di Kawasan PUSPIPTEK”. Jakarta, 2014. 
[15]. Keputusan Presiden No. 32 Tahun 1990 tentang pengelolaan Kawasan Lindung. Jakarta, 1990.

[16]. B. Susetyo, et al. "Analisis Spasial Kemampuan dan Kesesuaian Lahan untuk Mendukung Model Perumusan Kebijakan Manajemen Lanskap di Sempadan Ciliwung, Kota Bogor". Majalah Ilmiah Globe. Volume 16 No. 1 Juni 2014, Bogor, 2014.

[17]. R. Fuadhilah. "Timbulan dan Komposisi Sampah Sebagai Dasar Perancangan Teknis Operasional Persampahan pada Kecamatan Serpong, Serpong Utara, dan Setu sebagai Daerah Industri di kota Tangerang Selatan.” Skripsi Fakultas Teknik Program Studi Teknik Lingkungan, Universitas Indonesia. Depok, Juni 2012.
[18]. G. L. Elio Hakim. "Perubahan Penggunaan/ Tutupan Lahan Tahun 1990-2005 dan Proyeksi Perubahan Tahun 2020-2035 di Kawasan Jabodetabek". Skripsi Departemen IImu Tanah dan Sumberdaya Lahan, Fakultas Pertanian, IPB. Bogor, 2014.

[19]. R. Fajarini, B. Barus, D. R. Panuju. "Dinamika Perubahan Penggunaan Lahan dan Prediksinya untuk Tahun 2025 serta Keterkaitannya dengan Perencanaan Tataruang 2005-2025 di Kabupaten Bogor”. Jurnal Tanah Lingkungan. Volume 17 (1) April, ISSN 1410-7333, 2015 